\title{
Qualitative and Quantitative Characterization of Wood Fibers of Shrubs and Tree Species of the Tamaulipan Thorn Scrub, Northeastern Mexico and Its Possible Relation to Wood Quality and Utilization
}

\author{
Ratikanta Maiti', Humberto G. Rodriguez ${ }^{2}$, Aruna Kumari ${ }^{3}$ \\ ${ }^{1}$ Departamento de Quimica y Biologia, Universidad de las Americas, Santa Catarina Martir, Mexico \\ ${ }^{2}$ Facultad de CienciasForestales, Universidad Autonoma de Nuevo Leon, Linares, Mexico \\ ${ }^{3}$ Agricultural College, Jaya Shankar Telangana State Agricultural University, Jagtial, India \\ Email: ratikanta.maiti@gmail.com
}

Received 25 March 2016; accepted 9 May 2016; published 12 May 2016

Copyright (C) 2016 by authors and Scientific Research Publishing Inc.

This work is licensed under the Creative Commons Attribution International License (CC BY).

http://creativecommons.org/licenses/by/4.0/

(c) (i) Open Access

\begin{abstract}
The present study was undertaken to determine the variability in fiber cell morphology and its length among wood species of the Tamaulipan Thorn Scrub, Northeastern Mexico, used for various uses such as timber for furniture, fence, post, firewood and sources of forage. The results reveal large variability in fiber cell morphology and fiber cell dimensions. The species are classified on the basis of its fiber cell morphology and fiber cell length and recommended for their possible utilization for different purposes. Wood having fibre cells with broad lumen and thin wall could be suitable for the manufacture of paper documented in the literature viz. Acacia farnesciana, Caesalpinia mexicana, Cordia boisiieri, Diospyros palmeri, Forestieria angustifolia, Morus celtifolia, Prosopis laevigata. This technique can be used in preliminary screening of woody species for its utilization for different purposes. Further studies are needed to confirm.
\end{abstract}

\section{Keywords}

Wood Fiber Cells, Characterization, Variability, Woody Species, Wood Quality, Tamualipan Thorn Scrub 


\section{Introduction}

The shrubs and trees of the Tamaulipan Thorn Scrub in the semiarid regions of the North-eastern Mexico are of great economic importance for various uses such as timber for furniture, fence, post, firewood and sources of forage for wild grazing animals by containing various macro and micro-nutrients required by the animals, herbs, medicine and reforestation [1] [2]. The utilization of wood for different purposes depends on the structure, physical and chemical characteristics of wood elements, mainly fibre cells which impart mechanical strength to the plant.

The chemistry and ultrastructure of wood elements determines the properties of this lignocellulosic fiber of woody plants, and also determine longitudinal growth stress generated during cell-wall maturation as a result of the biosynthetic and biochemical processes during cell wall formation. There exist various types of reaction wood showing extreme cases of macromolecular and ultrastructural organization. Approximately half of the angiosperm species produce tension wood where the secondary wall is partially replaced by a so-called "gelatinous layer" where lignin is absent and made up of cellulosic microfibrils. The final fibre properties contribute greatly to the quality of pulp and paper as well as timber and its products.

There exists relationship between cell length and ring width and circumferential growth rate in Canadian species [3].

Studies have been undertaken on the cellulose microfibril angle in the cell wall of wood fibers. The term microfibril angle (MFA) in wood science is defined as the angle between the direction of the helical windings of cellulose microfibrils in the secondary cell wall of fibers and tracheids and the long axis of cell. The cellulose microfibrils are oriented in the $\mathrm{S}_{2}$ layer of the cell walls that forms the greatest proportion of the wall thickness and is responsible for the physical properties of wood. The authors made a review on the organization of the cellulose component of the secondary wall of fibers and tracheids and the various methods that have been used for the measurement of MFA. They observed a large variation of MFA within the tree observed between juvenile (or core) wood and mature (or outer) wood. This is of great importance in forestry for short rotation cropping of fast growing species [4].

A critical assessment of standing wood and fiber quality is made by [5] using ground and airborne laser scanning, physical and chemical characteristics of wood. The results show variations with both tree and site characteristics and also on the crown development, stem shape and upper layer, branch size and branch location, knot size, type and placement, age. All these characteristics determine wood properties, but also on stocking density, moisture, nutrient availability, climate, competition, disturbance, and stand ages have also been confirmed as key determinants of wood quality. They identified a number of key wood quality attributes (i.e. basic wood density, cell perimeter, cell coarseness, fiber length and microfibril angle) and established links between these properties and forest structure and site attribute. This technique is recommended to predict wood quality in standing timber.

The properties of wood and wood based materials are strongly dependent on the properties of its fibers; i.e., the cell wall properties. Therefore, there is a necessity to increase our understanding of structure-property relationships. The authors undertook a brief overview of the state of the art in experimental techniques to characterize the mechanical properties of wood at both the level of the single cell and that of the cell-wall [6].

A study has been made on the differences of wood elements (fiber cell and vessels) of Prosopis sp. in two locations of northeast Mexico and reported variation in fiber cell and xylem vessel length depending on precipitation and temperature. The location with high precipitation produced longer fiber length compared to other location having low precipitation and high temperature [7]. Another study revealed a gradual increase of the first two parameters with increase in distance from the pith to the periphery of the trunk and an inverse relation between for fiber diameter and the lumen diameter [8] [9] made characterization of fifteen woody species of Northeastern Mexico and its possible relation to wood quality.

\section{Materials and Methods}

\subsection{Study Site}

The study was undertaken in the municipality of Linares, Nuevo León in Forest Faculty of Universidad Autónoma de Nuevo León $\left(24^{\circ} 47^{\prime} \mathrm{N}\right.$; $\left.99^{\circ} 32^{\prime} \mathrm{O}\right)$, at sea level of $350 \mathrm{~m}$ snm. The type of climate present according to Köppen (1938), modified by Arcía (1981) (cited by [10]) is subtropical and semiarid condition with hot summer. The average monthly air temperatures oscillate between $14.7^{\circ} \mathrm{C}$ in January to $3^{\circ} \mathrm{C}$ in August, although 
the common temperature in summer is $45^{\circ} \mathrm{C}$. The average annual precipitation is approximately $805 \mathrm{~mm}$ with a bimodal distribution. This site is situated in soils which are dark brown deep vertisols. The predominant vegetation is Tamaulipan Thorn Scrub or subtropical thorn scrub [11].

\subsection{Methodology}

We adopted two techniques for maceration of wood for fibre studies.

- Technique 1. A small portion of wood is kept in a test tube in a mixture of $10 \%$ chromic acid: $10 \%$ nitric acid, then the mouth of test tube was plugged with cotton and kept in an incubator for 24 hours. Then the macerated wood tissue is washed carefully, stained with safranin and then mounted in a slide with glycerine for micro observation.

- Technique 2. R. K. Maiti developed a simple technique for the maceration of wood. Sampling of wood for fiber characterization. One disk of $0.1 \mathrm{~m}$ thick was taken from two primary branch of a tree from each species. Few small pieces of wood of each species were dipped in concentrated nitric acid and plugged with cotton. Then the test tubes are kept in boiling water bath until the wood pieces started disintegrating. Then acid was decanted slowly and the macerated wood elements were washed several times with distilled water. Then, the macerated fiber cells were stained with safranin (1\%) and observed under microscope and taken photographs with digital camera fixed with microscope. Fifty fiber cells of each species were measured using ocular and stage micrometer.

We took measurements in terms of length, breadth and cell wall of 50 fiber cells with the help of an ocular and a stage micrometer.

\section{Results and Discussions}

The followings are depicted the morphology of fiber cells of woods in the woody species of the Tamaulipan Thorn Scrub, and Wood fiber cells at $10 \times$ and $40 \times$.

\subsection{General Description}

In general wood fibre is a needle structure with a pointed apex, a lumen in the centre and cell wall. The morphology and dimensions of fibre cell such as cell length, lumen breadth and cell wall thickness vary among species.

\subsection{Description}

1) Acacia berlandieri. The lumen little broad, cell wall thin the apex pointed or round, the fibre cells little long.

2) Acacia farnesiana. The lumen broad, cell wall thick, the apex pointed, fibres cells uniform, few non-uniform.

3) Acacia rigidula. The lumen broad, cell wall thin, the apex is pointed.

4) Acacia shaffneri. The lumen little broad, cell wall thin, the apex pointed.

5) Acacia wrighti. The lumen thin, cell wall very thin, the apex pointed.

6) Bernardia myricifolia. The lumen little broad, cell wall thin, the apex pointed, fibres cells thin.

7) Caesalpinia Mexicana. The lumen is broad, cell wall very thin, the apex pointed, fibre cells little broad and little long, uniform.

8) Capsicum annuum. The lumen little broad, cell wall thin, the fibres long, the apex pointed.

9) Celtis laevigata. The lumen little broad, cell wall thin, but little, the apex round, few pointed.

10) Celtis pallid. The lumen thin, cell wall thin, the apex is pointed and round.

11) Condalia hookeri. The lumen thin, cell wall is thin, the apex pointed.

12) Cordia boissieri. The lumen little broad, cell wall thin, the apex pointed and round.

13) Croton terreyanus. The lumen thin, cell wall thin, the apex pointed or round.

14) Diospyros palmeri. The lumen little broad, cell wall is thin, the apex pointed.

15) Ehretia anacua. The lumen little broad, cell wall thin, the apex pointed.

16) Eysenhardtia polystachya. The lumen little broad, cell wall thin, the apex pointed, the fibre cells are uniform. 
17) Forestiera angustifolia. The lumen broad cell wall thin, the apex pointed, fibres long.

18) Fraxinus greggii. The lumen thin, cell wall thin, but little lignified, the apex pointed.

19) Gochnatia hypoleuca. The lumen thin, cell wall thick, the apex pointed or round.

20) Helietta parvifolia. The lumen thin, cell wall thin, the apex pointed.

21) Karwinskia humboldtiana. The lumen thin, cell wall thin, the apex pointed.

22) Lantana macropoda. The lumen little broad, cell wall thin but lignified, the apex pointed or round, the fibre cells small, large and thin.

23) Leucophyllum frutescens. The lumen thin, the apex pointed or round, the fibre cells small and thin.

24) Morus celtidifolia. The lumen little broad, the apex pointed, the fibre cells thin, uniform or non-uniform.

25) Parkinsonia aculeate. The lumen little broad, cell wall thin, but little lignified, the apex pointed.

26) Prosopis laevigata. The lumen little broad, cell wall thin, the apex pointed or round.

27) Quercus polymorpha. The lumen very thin, cell wall thin, the apex pointed, the fibre cells little long and thin, majority non-uniform.

28) Salix lasiolepis. The lumen broad, the cell wall thin, the apex pointed or round.

29) Zanthoxyllum fagara. The lumen thin, cell wall thin but lignified, the apex pointed or round.

30) Ziziphus obstusifolia. The lumen thin, cell wall thin, the apex pointed.

Microphotographs of wood fibre cells: $10 \times \& 40 \times$.

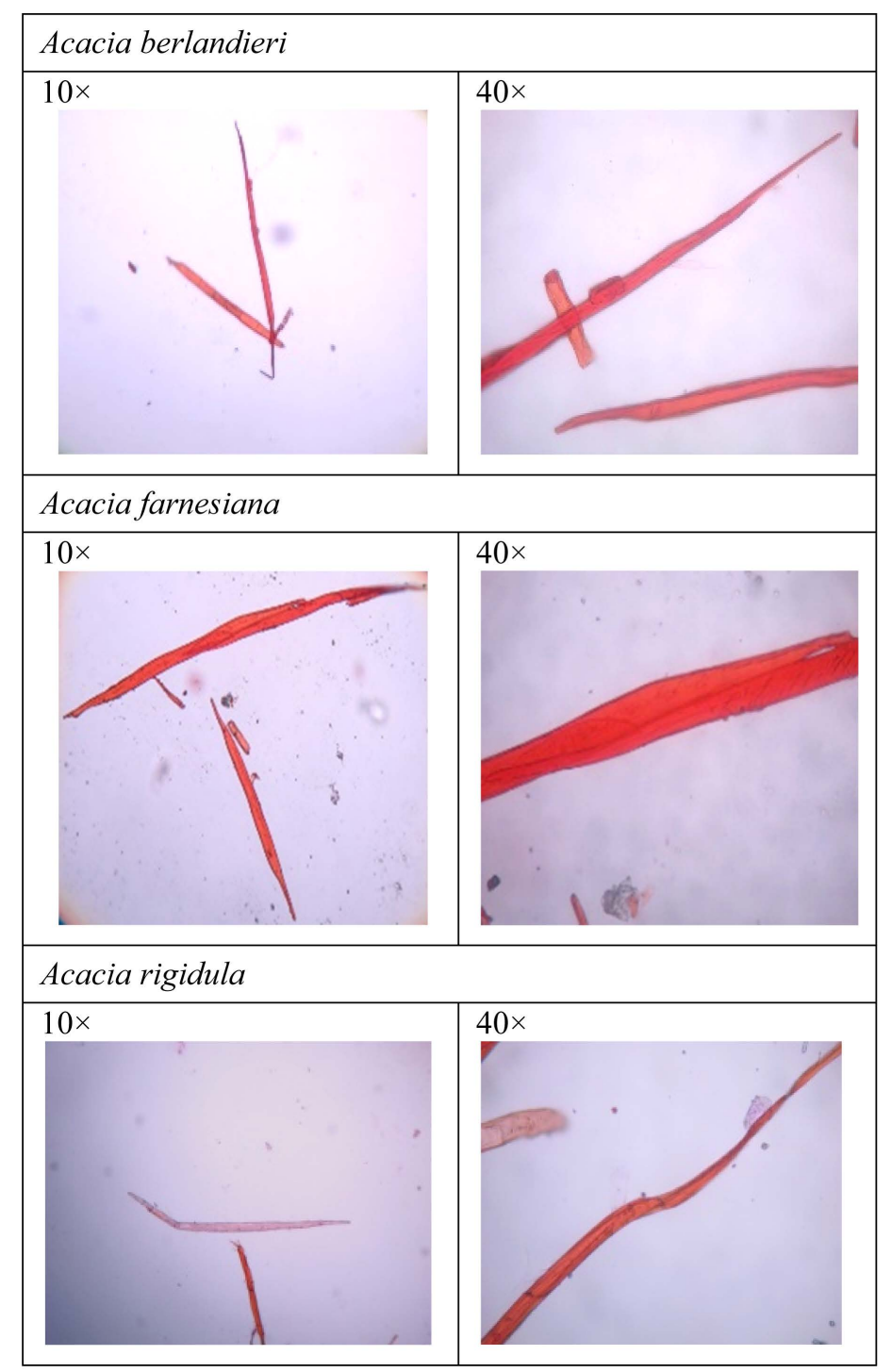



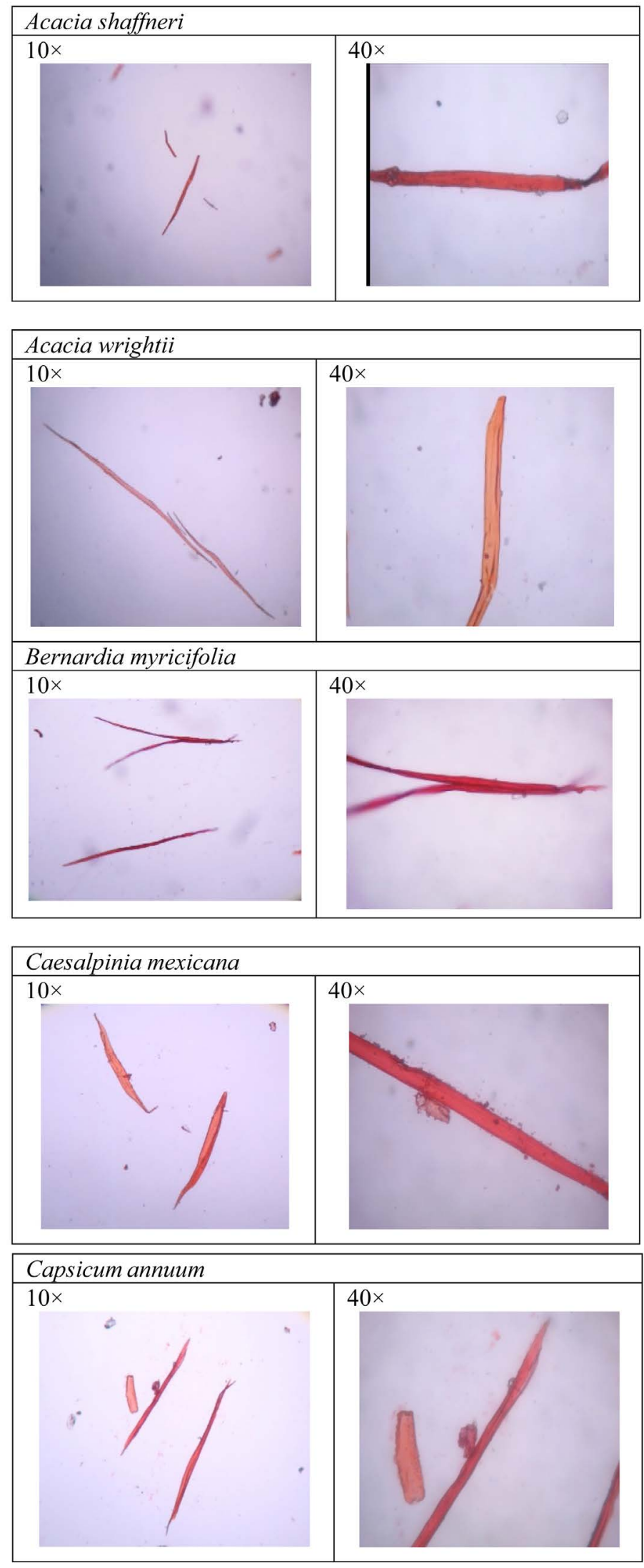

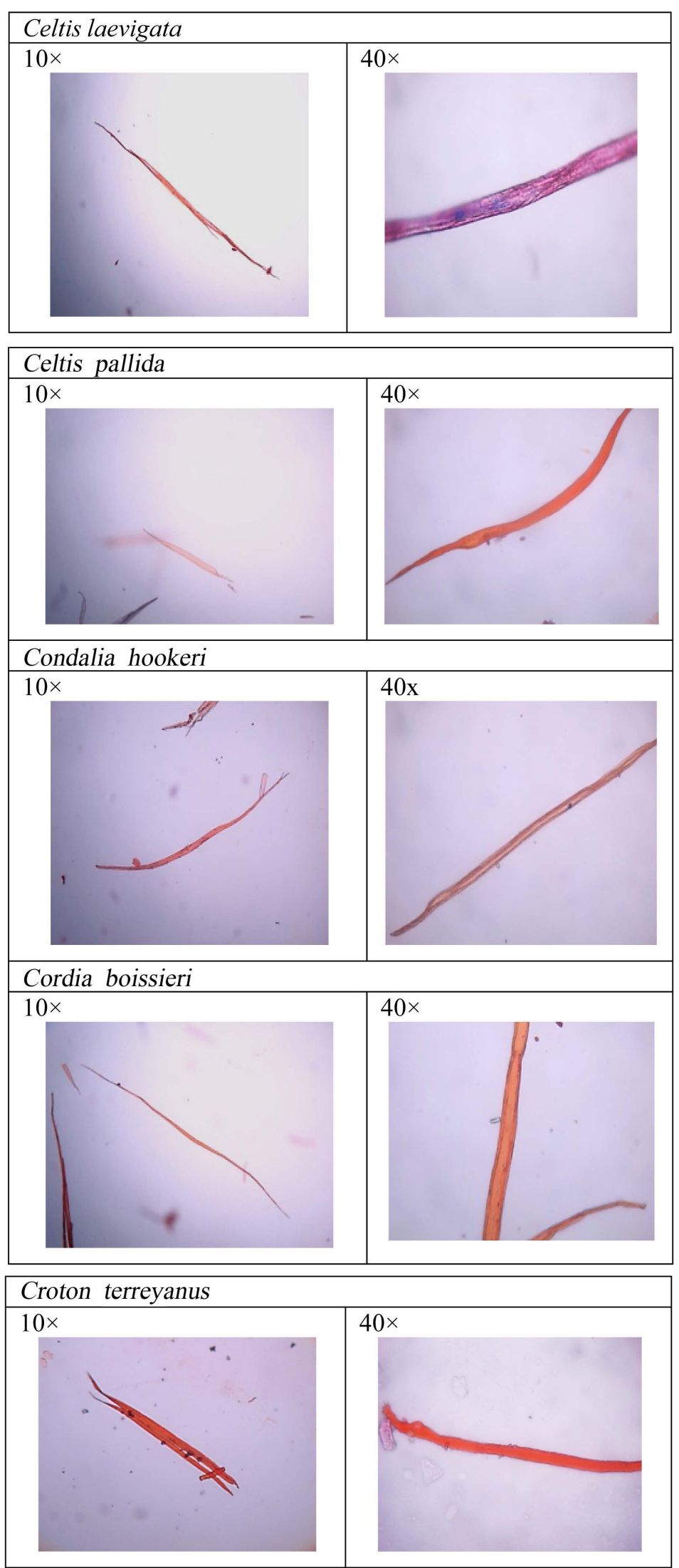

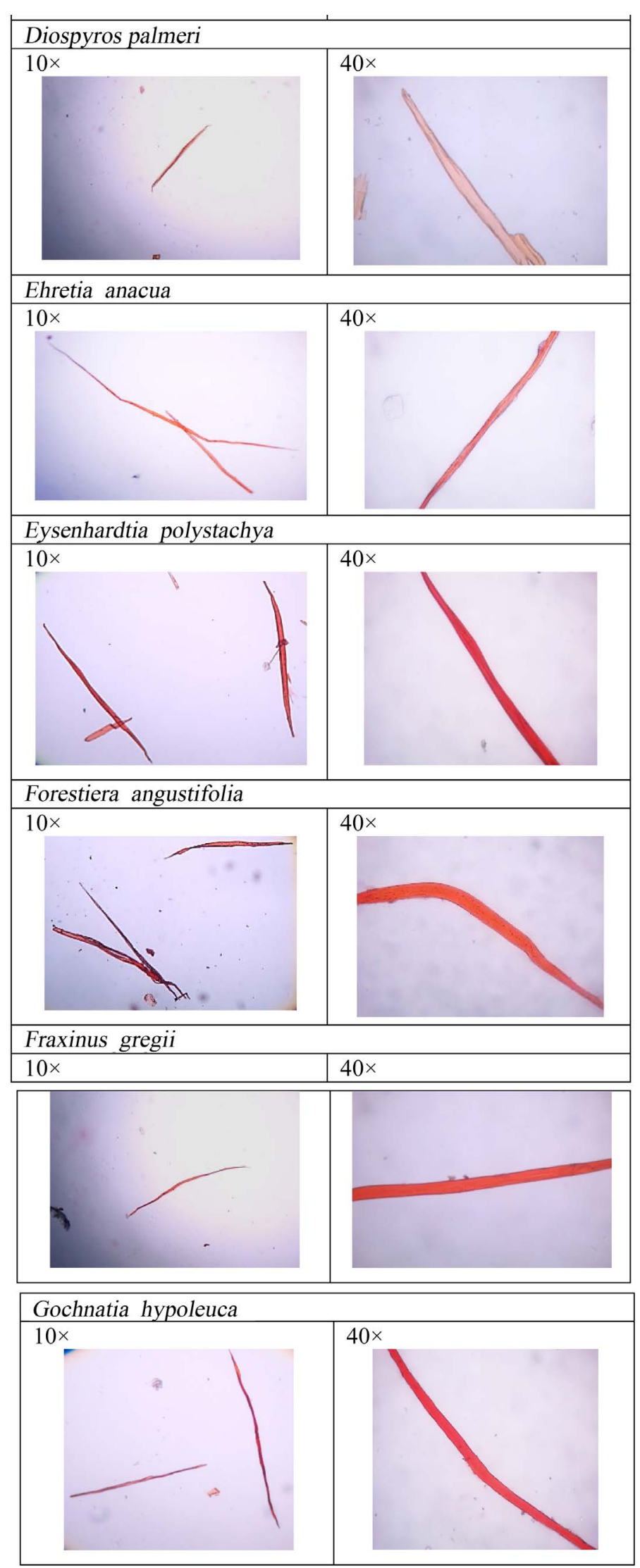

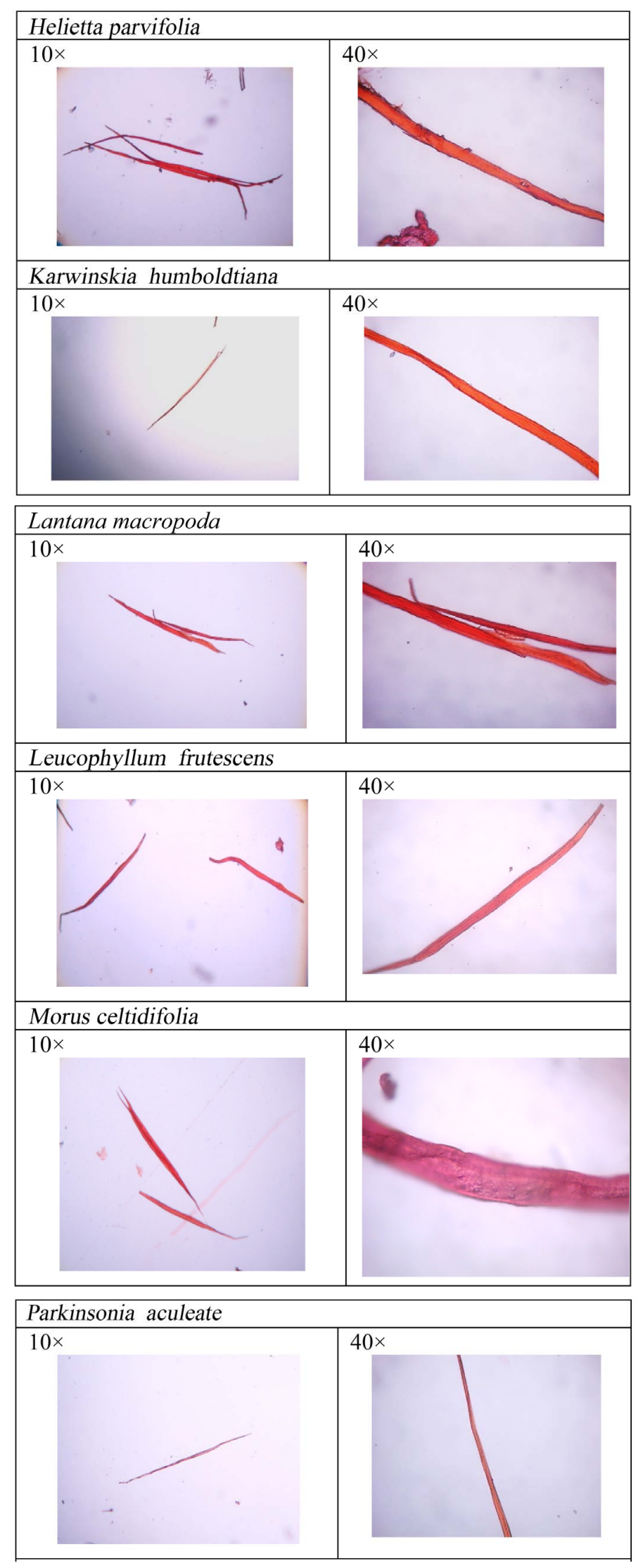

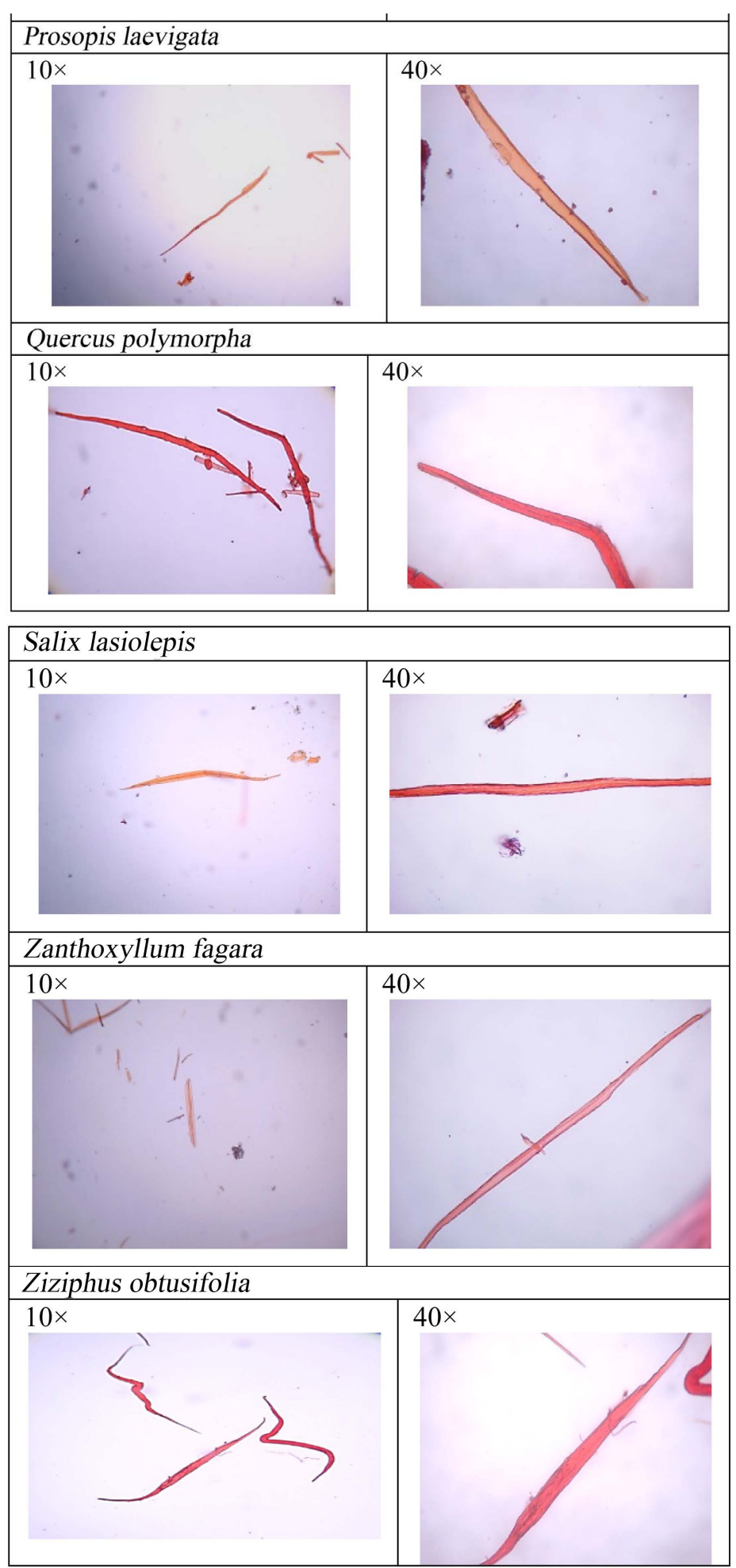

The species show a large variation in fibre cell length, breadth and wall thickness as shown in Table 1.

The main objective of this study was to investigate the variability in the morphology, size, shape and dimensions of fibers of 30 woody species. No attempts have been made to its physical quality and ultrastructure of the fibre cells. Many studies have been directed on the growth, ultrastructure and orientation of microfibrils in fiber cell walls. In the present study, large variations were observed in the size, shape of fiber cells among 
Table 1. Mean and standard deviation (SD) of fibre cell length, breadth and wall thickness of different plant species of the Tamaulipan Thorn Scrub, northeastern Mexico.

\begin{tabular}{|c|c|c|c|c|c|c|c|c|}
\hline \multirow{2}{*}{ Plant Species } & \multicolumn{2}{|c|}{ Fibrecelllength $(\mu \mathrm{m})$} & \multicolumn{2}{|c|}{ Breadth $(\mu \mathrm{m})$} & \multicolumn{2}{|c|}{ Wall thickness $(\mu \mathrm{m})$} & \multicolumn{2}{|c|}{ Length to breadth ratio } \\
\hline & Mean & SD & Mean & SD & Mean & SD & Mean & SD \\
\hline Acacia berlandieri & 464.01 & 159.70 & 23.52 & 7.40 & 2.98 & 1.42 & 19.73 & 21.58 \\
\hline Acacia farnesiana & 598.58 & 255.24 & 16.66 & 8.22 & 2.94 & 1.10 & 35.93 & 31.05 \\
\hline Acacia rigidula & 581.53 & 186.73 & 15.28 & 7.18 & 2.79 & 0.85 & 38.06 & 26.01 \\
\hline Acacia shaffneri & 501.17 & 248.84 & 16.85 & 9.90 & 2.94 & 1.48 & 29.74 & 25.14 \\
\hline Acacia wrightii & 438.06 & 214.92 & 15.68 & 6.56 & 2.89 & 0.95 & 27.94 & 32.76 \\
\hline Bernardia myricifolia & 450.59 & 105.04 & 22.73 & 8.72 & 3.13 & 1.48 & 19.82 & 12.05 \\
\hline Caesalpinia mexicana & 464.71 & 110.31 & 20.18 & 8.49 & 3.28 & 1.75 & 23.03 & 12.99 \\
\hline Capsicum annuum & 437.26 & 93.12 & 18.62 & 10.33 & 2.84 & 1.03 & 23.48 & 9.01 \\
\hline Celtis laevigata & 657.58 & 246.60 & 17.64 & 12.04 & 3.08 & 1.46 & 37.28 & 20.48 \\
\hline Celtis pallida & 471.97 & 162.82 & 14.11 & 6.9 & 3.08 & 1.08 & 33.45 & 23.60 \\
\hline Condalia hookeri & 398.47 & 161.13 & 17.64 & 10.09 & 3.23 & 1.52 & 22.59 & 15.97 \\
\hline Cordia boissieri & 518.03 & 155.09 & 16.46 & 7.25 & 3.72 & 1.8 & 31.47 & 21.39 \\
\hline Croton terreyanus & 453.53 & 101.78 & 14.73 & 7.67 & 3.23 & 1.15 & 30.79 & 13.27 \\
\hline Diospyros palmeri & 486.47 & 152.47 & 18.03 & 8.48 & 3.08 & 1.08 & 26.98 & 17.98 \\
\hline Ehretia anacua & 644.66 & 270.67 & 11.56 & 3.80 & 4.45 & 3.11 & 55.77 & 71.23 \\
\hline Eysenhardtia polystachya & 477.65 & 96.88 & 19.99 & 8.62 & 2.84 & 1.14 & 23.89 & 11.24 \\
\hline Forestiera angustifolia & 488.43 & 72.21 & 23.91 & 5.99 & 4.80 & 0.85 & 20.43 & 12.06 \\
\hline Fraxinus greggii & 535.67 & 150.90 & 17.64 & 13.42 & 2.74 & 1.17 & 30.37 & 11.24 \\
\hline Gochnatia hypoleuca & 563.30 & 176.16 & 17.24 & 5.79 & 2.94 & 1.21 & 32.67 & 30.42 \\
\hline Helietta parvifolia & 647.78 & 209.75 & 15.48 & 4.88 & 2.94 & 1.31 & 41.85 & 42.98 \\
\hline Karwinskia humboldtiana & 507.33 & 219.48 & 15.68 & 10.47 & 3.08 & 1.19 & 32.36 & 20.96 \\
\hline Lantana macropoda & 391.60 & 86.18 & 14.30 & 7.97 & 2.59 & 0.76 & 27.38 & 10.81 \\
\hline Leucophyllum frutescens & 438.45 & 94.49 & 16.66 & 7.47 & 3.08 & 1.19 & 26.32 & 12.65 \\
\hline Morus celtidifolia & 454.72 & 130.86 & 15.68 & 6.26 & 2.74 & 0.80 & 29.02 & 20.90 \\
\hline Parkinsonia aculeata & 473.33 & 110.03 & 31.64 & 8.55 & 6.86 & 0.98 & 14.96 & 12.87 \\
\hline Eysenhardtia polystachya & 477.65 & 96.88 & 19.99 & 8.62 & 2.84 & 1.14 & 23.89 & 11.24 \\
\hline Forestiera angustifolia & 488.43 & 72.21 & 23.91 & 5.99 & 4.80 & 0.85 & 20.43 & 12.06 \\
\hline Fraxinus greggii & 535.67 & 150.90 & 17.64 & 13.42 & 2.74 & 1.17 & 30.37 & 11.24 \\
\hline Gochnatia hypoleuca & 563.30 & 176.16 & 17.24 & 5.79 & 2.94 & 1.21 & 32.67 & 30.42 \\
\hline Helietta parvifolia & 647.78 & 209.75 & 15.48 & 4.88 & 2.94 & 1.32 & 41.85 & 42.98 \\
\hline Karwinskia humboldtiana & 507.33 & 219.48 & 15.68 & 10.47 & 3.08 & 1.19 & 32.36 & 20.96 \\
\hline Lantana macropoda & 391.60 & 86.18 & 14.30 & 7.97 & 2.59 & 0.76 & 27.38 & 10.81 \\
\hline Leucophyllum frutescens & 438.45 & 94.49 & 16.66 & 7.47 & 3.08 & 1.19 & 26.32 & 12.65 \\
\hline Morus celtidifolia & 454.72 & 130.86 & 15.68 & 6.26 & 2.74 & 0.80 & 29.03 & 20.90 \\
\hline Parkinsonia aculeata & 473.33 & 110.03 & 31.64 & 8.55 & 6.86 & 0.98 & 14.96 & 12.87 \\
\hline Prosopis laevigata & 412.97 & 190.85 & 10.78 & 2.96 & 2.84 & 0.90 & 38.31 & 64.48 \\
\hline Quercus polymorpha & 709.39 & 190.17 & 13.72 & 6.26 & 2.59 & 0.58 & 51.70 & 30.38 \\
\hline Salix lasiolepis & 455.11 & 150.25 & 16.07 & 6.78 & 3.43 & 1.30 & 28.32 & 22.16 \\
\hline Zanthoxyllum fagara & 454.13 & 155.80 & 16.07 & 8.57 & 3.23 & 1.15 & 28.26 & 18.18 \\
\hline Ziziphus obtusifolia & 591.09 & 150.72 & 20.58 & 7.20 & 2.98 & 1.33 & 28.72 & 20.93 \\
\hline
\end{tabular}


woody plant species. The present study shows large variability in fibre cell morphology of 30 species which coincides with that of [12].

On the basis of this we classify the species on the morphological characteristics of the fiber cells of the species studied.

Cell wall thin: Acacia berlandieri, Bernardia myricifolia, Helietta parvifolia, Leucop hyllumfrutescens, Quercus virginiana and Tribulus terrestris. The woods of these species may be recommended for soft furniture, fences and paper pulp.

Cell wall thin, lumen broad: Acacia berlandieri, Caesalpinia mexicana, Eysenhardtia polystachya, Forestiera angustifolia, Lantana macropoda and Morus celtidifolia. The wood of these species may be recommended for the preparation of paper pulp and good quality paper.

Cell wall thick, lignified, lumen narrow: Fouquiera splendens and Salvia officinalis. These species may be recommended for furniture and construction.

In the present study there were large variations in fiber cell length among different wood species on the basis of which we can tentatively classify different species.

Fiber cell medium long: Fouquiera splendens $(563 \mu \mathrm{m})$, Forestiera angustifolia $(488 \mu \mathrm{m})$, Eysenhardtia polystachya $(478 \mu \mathrm{m})$, Acacia farnesiana $(473 \mu \mathrm{m})$, Acacia berlandieri $(464 \mu \mathrm{m})$. It is expected that the wood of these species may offer moderate strength of wood and its products.

Fiber cells length: Quercus virginiana $(709 \mu \mathrm{m})$, Helietta parvifolia $(648 \mu \mathrm{m})$, Tribulus terrestris $(591 \mu \mathrm{m})$, Acacia farnesiana $(473 \mu \mathrm{m})$, Morus celtidifolia $(455 \mu \mathrm{m})$, Salvia officinalis $(454 \mu \mathrm{m})$. It is expected that the timbers of these species may offer greater strength to the wood and its products and papers.

Fiber cells short (less than $45 \mu \mathrm{m})$ : Lantana macropoda $(392 \mu \mathrm{m})$, Capsicum annuum $(437 \mu \mathrm{m})$, Leucophyllum frutescens $(438 \mu \mathrm{m})$. It is expected these timbers may offer poor strength to its woods and its products.

The present study was limited only in one locality as has been documented by various authors that fibre cell morphology, fibre cell length may vary across localities, environments and position in trees, variability studies are to be extended over localities.

We did not attempt to study the relationship between fiber cell length and timber quality which have been reported by various authors [13] (Maiti et al., 2011).

In addition, to fibre cell length, it is well known that high L/B ratio contributes to strength of bast fibres. In the present study, we selected the species having high L/B ratio: Ehretia anacua (56), Quercus polymorpha (51), Acacia rigidula (38), Celtis laevigata (37), Acacia farnesiana (36), Prosopis laevigata (38), Celtis pallida (33). The woods of these species may be recommended for better paper pulp and furniture.

The results reveal that there exists a large variability in wood anatomical traits which can be related in the species identification and quality determinations of the species. There is also large variability in the morphology, length, wall lignification of fibre cell in the woods among species. The intensity of lignification contributes to the strength and high quality timber for furniture. Soft wood containing high amount of parenchymatous tissue and thin walled fibre cells for fabrication soft furniture, fences. Wood having fibre cells with broad lumen and thin wall could be suitable for the manufacture of paper documented in the literature viz. Acacia farnesciana, Caesalpinia mexicana, Cordia boisiieri, Diospyros palmeri, Forestieria angustifolia, Morus celtifolia, Prosopis laevigata. Therefore, there is a great necessity to evaluate the wood anatomical structures of trees in a forest and classify them for their suitability of various uses on the basis of wood anatomical structure. The selected wood of a particular species could be tested for its physical and chemical properties in wood technology lab for its confirmation.

\section{References}

[1] Reid, N., Marroquín, J. and Beyer, M.P. (1990) Utilization of Shrubs and Trees for Browse, Fuel-Wood and Timber in the Tamaulipan Thornscrub, Northeastern Mexico. Forest Ecology and Management, 36, 61-79. http://dx.doi.org/10.1016/0378-1127(90)90064-I

[2] Stienen, H., Smits, M.P., Reid, N., Landa, J. and Boerboom, J.H.A. (1989) Ecophysiology of 8 Woody Multipurpose Species from Semiarid Northeastern Mexico. Annals of Forest Sciences, 46, 454-458. http://dx.doi.org/10.1051/forest:198905ART0101

[3] Fujiwara, S. and Yangk, K. (2000) The Relationship between Cell Length and Ring Width and Circumferential Growth Rate in Canadian Species, Wood. Iwawa Journal, 21, 335-345. 
[4] Barnett, J.R. and Bonham, V.A. (2004) Cellulose Microfibril Angle in the Cell Wall of Wood Fibres. Biological Reviews of the Cambridge Philosophical Society, 79, 461-472. http://dx.doi.org/10.1017/S1464793103006377

[5] Coops, T.N.C., Frazer, G.W., Wulder, M.A., Newnham, G.J. and Culvenor, D. (2011) Assessment of Standing Wood and Fiber Quality Using Ground and Airborne Laser Scanning: A Review. Forest Ecology and Management, 261, 1467-1478.

[6] Eder, M., Arnould, O., Dunlop, J.W.C., Hornatowska, J. and Salmén, L. (2013) Experimental Micromechanical Characterisation of Wood Cell Walls. Wood Science and Technology, 45, 461-472. http://dx.doi.org/10.1007/s00226-012-0515-6

[7] Carrillo, A., Foroughbachk, R., Bustamante, V., Wehenkel, C. and González, H. (2013) Natural Durability of Wood of Ten Native Species from Northeasern Mexico. Forest Science and Practice, 15, 160-166. http://dx.doi.org/10.1007/s11632-013-0201-2

[8] Velásquez, J., Jiménez, B., Monagas, P., Terzo, F.M., Toro, M.E. and Ruiz, Y. (2014) Aspectos morfológicos en las fibras de la madera de ErismauncinatumWarm. Interciencia, 39, 344-349.

[9] Maiti, R., Para, A.C., Rodriguez, H.G. and Paloma, S.V. (2015) Characterization of Wood Fibres of Scrubs and Tree Species of the Tamaulipan Thornscrub, Northeastern Mexico and Its Possible Utilization. Forest Research, 4, 4. http://dx.doi.org/10.4172/2168-9776.1000154

[10] González, H.R., Cantú, S.I., Gómez, M.M.V., Ramírez, L.R.G. and Uvalle, S.J.I. (2006) Producción de hojarasca y reciclado de nutrientesen el MatorralEspinosoTamaulipecoen el Noreste de México. Memoria del 2do Congreso Latinoamericano IUFRO, La Serena, Chile, 296 p.

[11] COTECOCA-SARH (1973) Coeficientes de Agostadero de la República Mexicana, Estado de Nuevo León. Secretaría de Agricultura y Ganadería, Comisión Técnico Consultiva para la determinación de Coeficientes de Agostadero, México.

[12] Maiti, R., Para, A.C., Rodriguez, H.G., Selena, V. and Paloma, A. (2015) Characterization of Wood Fibres of Scrubs and Tree Species of the Tamaulipan Thornscrub, Northeastern Mexico and Its Possible Utilization. Forest Research. (In Press)

[13] Maiti, R.K., Gonzalez-Rodriguez, H. and Satya, P. (2011) Horizon of World Plant Fibres: An Insite. Pushpa Publishing House, New Delhi, 178. 